\title{
ARCHETYPE ANALYSIS OF THE MAIN CHARACTERS IN \\ O. HENRY'S SHORT STORY THE GIFT OF THE MAGI (1905)
}

\author{
Mawar Dewanti Wandansari' ${ }^{1}$, Yulistiyanti ${ }^{2}$ \\ Faculty of Language and Cultural Studies, Stikubank University \\ e-mail: dewantimawar789@gmail.com¹, yulistiyanti@edu.unisbank.ac.id²
}

\begin{abstract}
This study is descriptive qualitative study, the focus of discussion is the archetypes of the characters in the short story "The Gift of the Magi" by O. Henry 1905. This short story represents a love story of a married couple who life in the low economic condition. The main characters are Jim as the husband and Della as the wife. It focuses on the explanation on the characters they have. There are some types of psichologycal study by Carl Jung (1953) that can be used to analyze, but the researcher only choose archetypes with three kinds: Ego, Soul, and Self. The researcher found the characteristics and the types archetypes they have. The most archetypes found is the Lover, it might happens because they are couple and the story tells about their struggle in doing the life together after married. This is also make the reader realize that love does not only come from something luxury, but also from suffering together. The result in this study is archetypes can be found in everytone. This sudy might give and improve the knowledge about artcehtypes for the researcher and readers.
\end{abstract}

Key words: archetype, O'Henry, The Gift of the Magi, Jung

\section{INTRODUCTION}

There are many psychic levels in the human personality. In the human life such as value, fear, hope, and others. That case called as archetype, also known as "universal symbol" or "constructed symbol". According to Jung, he saw psychic levels in the human personality, the level of conscious, and unconscious. He unconscious was divided into two categories: the personal unconscious and collective unconscious. Archetype itself belongs to collective unconscious. The archetype characteristics that humans have ; ego, soul and self. The Gift of the Magi, is an examples that can be analyzed by archetype.

The archetype in individual person proposed by Jung can be used to analyze artworks, it can be novel, poetry, short story, and so on. In this research, the researcher uses literary work from a short story entitled The Gift of the Magi by O. Henry (1905). According to Jung (1980), the ego represents the conscious mind as it comprises the thoughts, memories, and emotions a person is aware of. The ego is largely responsible for feelings of identity and continuity. Ego has four types: innocent, orphan, hero and caregiver. In the short story has two types who Della and Jim have. The story it contains the characters that can analyze the symbols using archetype theory proposed by Carl Gustav Jung (1981).

\section{STATEMENT OF THE PROBLEM}


According to the background of study, the statement of the problem can be formulated as follows:

1. What are the characteristics of the main characters of O. Henry's The Gift of the Magi?

2. What are the archetype of the main characters of O. Henry's The Gift of the Magi?

\section{METODOLOGY}

Jung claimed that to" smile, cry, or the neutral ability of sucking in the newborn is archetypal. Similarly, all repetitive behaviors and gestures which define us as humans are of archetypal forms" (Jung, 1981). The researcher used psychological approach it leads to substantial of the literary work's meaning. They are researcher used the theory of archetype by Carl Jung to support the analysis used the data from O. Henry's short story entitled The Gift of the Magi that was published in 1905. The data analysis procedures have been done as follows, read the whole data and recognize the citations that contain the case related to the theory, identify the archetype in the story, and interpret the findings and analyze it using archetype theory.

\section{THEORETICAL REVIEW}

The first is ego. It comprises the thoughts, memories, and emotions that a person aware. The next point is personal unsconscious. The unconscious would contain only those elements of the personality which could just as well be conscious, and have in fact been suppressed only through the process of education (Jung, 1953). The personal unconscious contains lost memories, painful ideas that are repressed, subliminal perceptions, by which are meant senseperceptions that were not strong enough to reach consciousness, and contents that are not yet ripe for consciousness. The figure of the shadow so frequently met with in dreams can be corresponded. Jung told the important things of the unconscious complex called as persona. He says persona is the individual's system of adaptation to the manner they assume in dealing with. Persona is the public image of someone to locate their position in society between people. The original word persona means mask, it is wore by people in order to impose a certain image in different role: father, mother, chief, artist, official, teacher, president of republic, etc. The complex is a collection of attitudes, thoughts, feelings, and memories focused on a concept. Every proffesion has its own persona.

And the last one is collective unconscious. That is why the content of the collective unconscious is more or less the same for each person in all cultures because it experiences with universal symbol like water, God, noon, etc. The collective unconscious might 
influences one's thoughts, emotions, and actions. It is responsible for having trust in religion, myths, and legends but it does not refer the ideas that derived rather to the strong tendency of humans. Unconscious manifestations can be as symptoms and complex, dream and archetype. According to Jung (1919), the collective unconscious contains archetype or the universal primordial ideas and images.

\section{ANALYSIS AND DISCUSSION}

\section{Archetypes of the Main Characters}

There are two main characters analysed in this research. They are a couple named Jim as the husband and Della as the Wife. According to Jung's theory, their characteristics are analyzed based on Ego, Soul, and Self. Those are explained below:

\section{Della}

Della is one of the main characters in the short story The Gift of the Magi. There are some quotations which show Della's characters that can be analyzed using archetypal theory.

\section{A. Ego}

In Ego, it included Innocent, Orphant, Hero, and Caregiver. But Della only has two of ego archetypes. At the beginning of the story, Della is potrayed as a Hero. This is a quotation stated at the first paragraph of the story:

"ONE DOLLAR AND EIGHTY-SEVEN CENTS. That was all. She had put it aside, one cent and then another and then another, in her careful buying of meat and other food. Della counted it three times." (Page 1)

According to the paragraph above, she has a hero archetype especially in the sentence "...in her careful buying of meat and other food." The Hero is not only saving a sink person, a cat on the high tree, or rescue someone in the fire, the Hero also does anything to avoid losing things even from the simple things. The sentence shows that Della tried to avoid more number of money lost, she bought everything for daily needs carefully to save money from her husband.

It is also prooved in the sentence:

"She put on her old brown coat. She put on her old brown hat."(Page 3)

Della was not only saving Jims little salary by careful in buying daily needs. She is also careful in buying fashion and doing style. The author said that Della wore "old brown coat" and "old brown hat", it shows Della does not want to waste more money to buy something new. Meanwhile women commonly like to upgrade their style and competite with others. In 1905, the women's style mostly wear elegant dress, it might be expensive. As a Hero, Della 
likes to save something from the simple one. By saving the money it means Della did simple thing to safe the continue of her and Jims life. The daily needs are fulfilled, she can also do other thing with the money she spent without disturbing Jim.

The second Ego archetype Della having is the Caregiver. Such in the quotation below:

"If a queen had lived in the rooms near theirs, Della would have washed and dried her hair where the queen could see it. Della knew her hair was more beautiful than any queen's jewels and gifts." (Page 2)

"So now Della's beautiful hair fell about her, shining like a falling stream of brown water. It reached below her knee. It almost made itself into a dress for her." (Page 3)

In the paragraphs above, the author says Della has very long and beautiful hair, it was below the knee. A Caregiver protects and prevents any danger that come to something they love. Here, Della protects her hair nicely and prevents it from being broken. In the researcher's environment, women commonly have hair just as long as the shoulder or their backs, even there are also who cut their hair above the shoulders and it is looks like a man. If there is a woman who has hair that the lenght is under the knee, it can show us if she is a caregiver. Della gave cares her hair. It is pretty and adorable as quoted:

"shining like a falling steam of brown water.” (Page 3)

It is even more beautiful than any jewels the queens have. That is why Jim falls in love with his wife's hair.

Long hair usually will be more tangled than short hair, Della is patient enough in caring the hair by washing, combing, and doing more treatment. Today, there are a lot of hair treatment product like shampoo, conditioner, and hair spa. The story was written in 1905, every part of the story might happen around that year too, when the hair treatment products are not as much as nowadays.

\section{B. Soul}

Soul included Explorer, Rebel, Lover and Creator. Della is a warm person. In the story, the researcher does not find Rebel and Creator archetype in Della, but the researcher found some citations wich are match to Explorer and Lover archetypes.

"Oh, and the next two hours seemed to fly. She was going from one shop to another, to find a gift for Jim. She found it at last. It surely had been made for Jim 
and no one else. There was no other like it in any of the shops, and she had looked in every shop in the city." (Page 3)

"Isn't it perfect, Jim? I hunted all over town to find it. You'll have to look at your watch a hundred times a day now. Give me your watch. I want to see how they look together." (Page 6)

An Explorer likes to search for perfection. She was willing to walk around the city just to select the perfect gift for Jim. A person who does not have big love or care to the husband, she would only buy any gift without considering which one is suitable. Maybe she would only stay in a shop and choose one. But Della is different, she explored the city to find something perfect for Jim and she is satisfied.

At the begining, the author said:

"There was nothing to do but fall on the bed and cry. So Della did it." (Page 1)

In the sentences above, Della cries because she cannot spend a lot of money to buy a gift for Jim. She is a serious person who might be easy to get depressed about love. She cries even for something simple, that is gift. In the story, O. Henry did not mention how long they have been together, but this might be not their first Christmas. They might bring gift for each other in the last Christmas and it is okay if they do not bring gift anymore due to the financial condition. But Della thinks serious about it because she might be afraid to be unlove and did not want to make Jim upset.

Other quotations:

"Within forty minutes her head looked a little better. With her short hair, she looked wonderfully like a schoolboy. She stood at the looking-glass for a long time." (Page 4)

"If Jim doesn't kill me," she said to herself, "before he looks at me a second time, he'll say I look like a girl who sings and dances for money. But what could I dooh! What could I do with a dollar and eighty-seven cents?" (Page 4)

"She often said little prayers quietly, about simple everyday things. And now she said: "Please God, make him think I'm still pretty." (Page 4)

A person with Lover archetype has fear to be unloved. In the quotations above, Della is afraid if Jim would not think if she is pretty then turning to not love her anymore. In 1905, most women might be having thought that a long hair means elegance. That is why when Della cut her hair very short, she is affraid to be looked like a school boy or a naughty woman who dance for money. It means that might create Jim's negative thought, it can give impact to Della if Jim left her. She will be unloved, unwanted and alone. 
"Jim, dear," she cried, "don't look at me like that. I had my hair cut off and sold it. I couldn't live through Christmas without giving you a gift. My hair will grow again. You won't care, will you? My hair grows very fast. It's Christmas, Jim. Let's be happy. You don't know what a nice-what a beautiful nice gift I got for you." (Page 4-5)

The feel of affraid being unloved, unwanted, and alone is continued here, when Jim looks at her like he looks to stranger. She tries to make Jim understand if her hair would grow fast so he would not regret of her one-side decision. She sacrificed her long and beautiful hair to buy a gift for Jim. Hair is a nature gift from God, when someone lost it, she could not find it nowhere. She even has known the risk she gets after selling the hair, but she keeps doing it.

"Della held the watch chain in her hand and sat near the door where he always entered. Then she heard his step in the hall and her face lost color for a moment." (Page 4)

As a Lover, Della does everything with heart however for a simple things. The quotation above shows if Della knows exactly the behavior of Jim that is where he entered the room after working. She wanted to make Jim feel being loved and wanted. She has a strong feeling toward other, and here, without communication through phone, Della knows when he returned home from the hour, minutes, and second because she always learnt Jim's behavior by heart. She sat near the door where he always entered when coming home. Nowadays, in 2020, some wives are busy when the husband back home. They maybe just stay in the room, watch television, operate social medias, or care for childern. But in this story, the author did not mention about kids, so Della has more time to care for his husband.

\section{Self}

The self is included Jester who likes to joke and entertaint people, Sage who likes to find the truth using intelegence and knowledge, Magician who likes to make dreams come true by developing vision and livin on it, and the last is Ruler who likes to control people around him. In the story, the researcher did not find any quotation that support Della's character in Self.

\section{Jim}

Jim is another the main character in the short story The Gift of the Magi. The writer found some quotations which show Jim's characters that can be analyzed using archetypal theory. 


\section{A. Ego}

Different from Della, the researcher only found Hero archetype in Jim's character.

"The door opened and Jim stepped in. He looked very thin and he was not smiling. Poor fellow, he was only twenty-two-and with a family to take care of! He needed a new coat and he had nothing to cover his cold hands." (Page 4)

Jim works very hard. His body is thin. When he went home he was not smiling, it might be caused he got pressure in working. As a person who has Hero archetype, Jim never gives up however he thinks about the family, work, and continue living with low salary. He even does not have coat or something to cover his hands.

Jim is also a Caregiver such in the paragraph:

"If a king had lived in the same house, with all his riches, Jim would have looked at his watch every time they met. Jim knew that no king had anything so valuable." (Page 2-3)

Caring is not only for the living thing. A Caregiver wants to protect others from harm things. Jim cares for the old watch from his father that belonged to his grandfather too. Caring an old thing is not easy, Jim watch's age approximately more than twenty years. Caregiver protects any danger happened to the thing or person he cares for. He might repair, change the battery, do some polish and clean routinely to avoid the watch broken. However at the end the watch is sold to buy gift for Della, at least this case shows that Jim is a Caregiver who cares for the old watch for long time.

\section{B. Soul}

Same with Della, Jim has many quotations which shows a Lover archetype. Such as:

"Jim put his arms around his Della. For ten seconds let us look in another direction." (Page 5)

Physically, Jim likes Della's hair so much like in the quotation:

"The James Dillingham Youngs were very proud of two things which they owned. One thing was Jim's gold watch. It had once belonged to his father. And, long ago, it had belonged to his father's father. The other thing was Della's hair.” (Page 2)

But he still loves her even though Della cut her hair. A Lover becomes more and more physically attractive to have relation with people and surrounds they love. Jim attracted to Della's hair, but he is more than that. He loves Della whatever the hairstyle, he might believe that Della's hair will grow again and turns as beautiful as before. This might show faith their 
love is. Jim does not regret, he behaves like Della still owns her long hair. without decreasing his love, he hugs Della. For a husband who only loves the wife because the physic, he might might angry and upset if his wife cut the hair does not like what he wanted.

Hair is not an expensive things. Hair as a simple thing that Della own has special part of Jim's life. Jim loves Della's hair like he loves the gold watch that belonged to his grandfather. He even said "Nothing like a haircut could make me love you any less". In 2020, it might be hard to find a lover like this.

"Della," said he, "let's put our Christmas gifts away and keep them a while. They're too nice to use now. I sold the watch to get the money to buy the combs. And now I think we should have our dinner." (Page 6)

A lover is a warm and kind person. Jim is not a selfish person, they give gift each other but Jim prefer to have dinner with Della. He does not care with the gift, the most important for him is the love between him and his wife. At the end, the author tells that Jim and Della are the representation of the Magi. It has explained in the previous point.

\section{Self}

Similar with Della, the researcher did not find any quotations which are suitable with Jim and Self Archetype. Moreover, the role of Jim is less than Della. Jim did not make any jokes to entertaint Della. He did not try to make dreams come true or control people around him.

\section{CONCLUSION}

The researcher concluded that the theory used to answer the second problem statement is Carl Jung's Psychoanalysis theory, especially archetypes. Jung has 3 human psyche: Ego, Personal Unconcious, and Collective Unconscious. Collective Unconscious is also known as Archetype. In human's life, Archetype has importatnt role to give impacts on people. It can be caused by three types of archetypes; Ego, Soul, and Self. Each types has four characteristics. The first is Ego that has Innocent, Orphant, Hero, and Caregiver. The second is Soul that has Explorer, Rebel, Lover, and Creator. The last is self, Self has Jester, Sage, Magician, and Ruler. Those characteristics of archetypes exist in human's psyco, but only some who are owned by Jim and Della.

The most archetypes that they have are the Ego (the Caregiver character) and Soul (the Lover character). They are good in caring their valuable things. Not all women can take care 
of their hair until it gros very long, Della's long hair is below the knee. Moreover hair is a sensitive part that is easy to be tangled. Jim did so, not all men can take care of the old watch. However the chain might be broken or lost and he could not buy the new one due to the financial condition.

Many souls are displayed by the characters. In the story, Jim and Della more show their Love archetypes. It might happen because they are a married couple who struggle continuing life together.. A Lover archetype likes to be loved and afraid to be unloved. In here they show their loves to each other so that they will be felt like they are being loved everytime. However in showing the love, they have to sacrifice their most valuable things. It means that for them, partner is much more important han the most valuable things that they have sold for buying gifts. In 2020, it is hard to find loyal person to be stay us in every conditions. There are many modern things who support people become cheater. One of them is online social media that does not exist yet in the year of the story is being written.

In self, the researcher did not find their characters in there because it mostly does not talk about love. It is talked more about freedom of self. Looking for something independently, leading someone or some groups, breaking the rules or being jokers. Jim and Della do not have those kinds of archetypes.

They are the representation of Magi. The interpretation of the Magi in the story The Gift of the Magi is three wise men who brought gifts to the baby Jesus who was just born. They brought gold, frankincense and myrh because they were the symbol of great value (Williamson, 2019). Della and Jim willingly bring gifts for each other in order to make each one happy. In the end, Jim and Della prefer to have dinner to fill their time with beautiful moments in the christmas as the special day instead of giving impression toward their new gifts.

\section{BIBLIOGRAPHY}

Adams, Kristina. 2018. 9 Character Types to Include in Your Story. Downloaded from https://www.writerscookbook.com/character-types-story/ (December 13, 2019)

Aritonang, Veronika. 2018. Figurative Languages in O. Henry's Short Stories. University of North Sumatra. Downloaded from http://repositori.usu.ac.id/bitstream/handle/123456789/3942/130705112.pdf?sequence= $\underline{1 \& \text { is Allowed }=y}$ (November 5, 2019) 
Bhatnagar, M. K. 2001. Encyclopaedia of Literature in English. Atlantic Publishers and Disributors: New Delhi, India. Downloaded from

https://books.google.co.id/books?id=g5rjCHjQp98C\&printsec=frontcover\#v=onepage \& $\mathrm{q} \& \mathrm{f}=$ false $($ October 19, 2019)

Christou, Evangelos. 1987. The Logos of Soul: Volume 2 of Dunquin Series. University of Michigan: Spring Publications. Downloaded from https://books.google.co.id/books/about/The_Logos_of the_Soul.html?id=S12HreH0esC\&redir_esc=y $($ December 13, 2019)

Grant, Matt. 2017. The Difference Between Fiction and Nonfiction. Riot New Media Group. Downloaded from https://bookriot.com/2017/11/02 /difference-between-fiction-andnonfiction/ (November 20, 2019)

Haase, Ryan. 2019. Author Study: O. Henry. Downloaded from https://www.mrhasee.com (October 19, 2019)

Henry, O. 1905. The Gitf of the Magi. Downloaded from Error! Hyperlink reference not valid._(September 20, 2019)

J. Menrath. 2003. Definition of the Short Story. Downloaded from http://www.menrathonline.de/documents/shortst2.pdf (November 20, 2019)

Jung, C. G. (1934-1954). The Archetypes and the Collective Unconscious. (1981 2nd ed. Collected Works Vol.9 Part 1), Princeton, N.J.: Bollingen. ISBN 0-691-01833-2.

Jung, Carl Gustav. 1953. Two Essays in Analytical Psychology; Volume 7. London. Downloaded from https://www.jungiananalysts.org.uk/wp-content/uploads/ 2018/ 07/C.-G.-Jung-Collected-Works-Volume-7_-Two-Essays-on-Analytical-Psychology.pdf (December 19, 2019)

Laksono, Imam Setyojati Sedyo. 2015. Situational Archetype Analysis on Demian Karras in William Petter Blattty's “The Exorscist”. Islamic State University of Malang.

Lambert, Clinton E. 2012. Qualitative Descriptive Research: An Acceptable Design. Pacific Rim International Journal of Nursing Research.

Macdonald, Edgar. 1994. Porter, Wiliam Sydney (O. Henry). Downloaded from https://ncpedia.org/biography/porter-william-sydney-o (September 28, 2019)

Martin, Jonathan. O. Henry (1862-1910). Downloaded from https://northcarolinahistory.org/encyclopedia/o-henry-1862-1910/ (September 28, 2019)

McFadden, George. 1978. 'Literature’: a many-sided process. Pages: 49-61.

Meyer, Jim. 1997. What is Literature? A Definition Based on Prototypes. University of North Dakota Session. Downloaded from 
https://pdfs.semanticscholar.org/6960/1419639f2cd71e65cc6628f75441f2efc4b1.pdf (November 5, 2019)

Neill, Conor. 2018. Understanding Personality: The 12 Jungian Archetypes. Downloaded from https://conorneill.com/2018/04/21/understanding-personality-the-12-jungianarchetypes/ (December 12, 2019)

O. Henry's Biography. Downloaded from https://m.imdb.com/ name/nm0377958/bio (October 19, 2019)

Pranusai. 2001. O Henry Essay. Downloaded from https://www.termpaperwarehouse.com/essay-on/Ohenry/261201 (October 19, 2019)

Pursey, Kirstie. 2016. What Are the 12 Archetypes and Which One Dominates Your Personality. Downloaded from https://www.learning-mind.com/12-archetypes/ (December 11, 2019)

Sharp, Daryl. 2019. The Soul of Carl Jung: Jungian Terminology. Downloaded from https://carljung.co/ (December 12, 2019)

Sili, Surya, et all. 2018. An Analysis of Main Characters in Warm Bodies Film Using Jung Theory of Archetypes. Mulawarman University: Department of English Literature.

Stamper, Mary. 2013. This Talk of Soul: What Does It Mean? Downloaded from https://cgjungpage.org/learn/articles/book-reviews/890-this-talk-of-soul-what-does-itmean (December 12, 2019)

Team of Explore Your Mind. 2019. The Twelve Jungian Archetypes. Downloaded from https://exploringyourmind.com/twelve-jungian-archetypes/ (December 11, 2019)

McClellan, Elias. 2017. Writing a Main Character: Definitions, Tips and Examples. Downloaded from https://www.nownovel.com/blog/main-character-writing/ (December 13, 2019)

Walter, Elizabeth, and Cranz Diane. 2008. Cambridge Advanced Learner Dictionary. Cambridge University Press.

Wenzel, Amy. 2017. The SAGE Encyclopedia of Abnormal and Clinical Psychology: Psychoalaysis. SAGE Publication: Thousand Oaks. Downloaded from https: //www.researchgate.net/publication/ 316011507_Psychoanalysis (November 11, 2019) 